\title{
BIOMASS ACCUMULATION IN FORESTS WITH HIGH PRESSURE OF FUELWOOD EXTRACTION IN CHIAPAS, MEXICO ${ }^{1}$
}

Deb Raj Aryal ${ }^{2 *}$, Roldan Ruiz Corzo ${ }^{3}$, Alonso López $\mathrm{Cruz}^{4}$, Carlos Velázquez Sanabria ${ }^{4}$, Heriberto Gómez

Castro $^{3}$, Francisco Guevara Hernández ${ }^{3}$, René Pinto Ruiz ${ }^{3}$, José Apolonio Venegas Venegas ${ }^{2}$, Alejandro

Ley de Coss $^{3}$, Danilo Morales Ruiz ${ }^{3}$ and Isaí Euán Chi ${ }^{5}$

\begin{abstract}
${ }^{1}$ Received on 03.05.2018 accepted for publication on 31.07.2018.
${ }^{2}$ CONACYT-Universidad Autónoma de Chiapas, Facultad de Ciencias Agronómicas, Chiapas - México. E-mail: <drajar@conacyt.mx>, and <polo_tex1@hotmail.com>.

${ }^{3}$ Universidad Autónoma de Chiapas, Facultad de Ciencias Agronómicas, Chiapas - México. E-mail: <ruizc.roldan@ gmail.com>, <hgomezc1@yahoo.com>,<francisco.gouvara@unach.mx>,<pinto_ruiz@yahoo.com.mx>, <alejandro.ley@unach.mx>and $<$ moraless@outlook.com>.

${ }^{4}$ Biodiversidad, Medio Ambiente,Sueloy Agua, Chiapas - México. E-mail: <alonsoloc75@ gmail.com> and <cavs58@gmail.com>. ${ }^{5}$ Universidade Federal de São Carlos, Programa de Pós-Graduação em Planejamento e Uso de Recursos Renováveis, Sorocaba, SP - Brasil. E-mail: <iessaiec@gmail.com>.

*Corresponding author.
\end{abstract}

\begin{abstract}
Tropical forests plays a vital role in mitigating atmospheric $\mathrm{CO}_{2}$ but the retention capacity of such ecosystems has changed greatly due to increasing anthropogenic pressures, of which firewood extraction is the main one activity in rural areas. The purpose of this research was to evaluate the biomass stocks of pine and oak forests with different pressure of fuelwood extraction in Chiapas, Mexico. The study was carried out in four locations in the state of Chiapas, southern Mexico; two of them with high extraction levels and the other two with lower extraction levels. Pine and Oak forests are the predominant forest types in the region. A total of sixteen plots of $400 \mathrm{~m}^{2}$ were established to measure the biomass stocks of the trees with $\geq 7.5 \mathrm{~cm}$ DBH. Published allometric equations were used to quantify the biomass stocks. The average biomass of the pine forest with low fuelwood extraction was $213.4 \mathrm{Mg} \mathrm{ha}^{-1}$, and that of the oak forest was $189.5 \mathrm{Mg} \mathrm{ha}^{-1}$. On the other hand, the biomass stocks of the pine forest with high fuelwood extraction was $138.2 \mathrm{Mg} \mathrm{ha}^{-1}$, and that of the oak forest was $92.0 \mathrm{Mg} \mathrm{ha}^{-1}$. Communities with agricultural diversification like apiculture and agroforestry practices were found more effective in forest biomass conservation when compared to those who are only dedicated to Milpa cultivation and extensive bovine livestock production. The adoption of silvopasture systems, the use of crop residues and the use of ecological cooking stoves can be the alternatives to reduce forest fuelwood extraction.
\end{abstract}

Keywords: Aboveground biomass; Anthropogenic pressure; Firewood

\section{ACUMULAÇÃO DE BIOMASSA EM FLORESTAS COM ALTA PRESSÃO NA EXTRAÇÃO DE LENHA EM CHIAPAS, MÉXICO}

\begin{abstract}
RESUMO - As florestas tropicais desempenham um papel vital na mitigação do $\mathrm{CO}_{2}$ atmosférico, mas a sua capacidade de retenção mudou devido ao aumento das pressões antropogênicas, das quais a extração de lenha é a principal atividade nas áreas rurais. O objetivo deste estudo foi avaliar o estoque de biomassa nas florestas de pinus e carvalho com diferente pressão na extração de lenha em Chiapas, México. O estudo foi realizado em quatro localidades no Estado de Chiapas, sul do México, duas com maior extração de lenha e duas com menor extração. Florestas de pinus e carvalho predominam na região. Um total de dezesseis parcelas de $400 \mathrm{~m}^{2}$ foram estabelecidas para medir os estoques de biomassa das árvores com DAP $\geq 7,5$ $\mathrm{cm}$. A biomassa foi calculada mediante equações alométricas publicadas. O estoque médio de biomassa na floresta de pinus com menor extração de lenha foi de 213,4 $\mathrm{Mg} \mathrm{ha}^{-1}$ e da floresta de carvalho foi de 189,5 $\mathrm{Mg} \mathrm{ha} \mathrm{g}^{-1}$. Por outro lado, o estoque de biomassa em florestas de pinus com maior extração de lenha foi de 138,2 $\mathrm{Mg} \mathrm{ha}^{-1}$ e da floresta de carvalho foi de 92,0 $\mathrm{Mg} \mathrm{ha}^{-1}$. Comunidades com diversidade agrícola, como apicultura e práticas florestais, foram consideradas mais eficazes na conservação da biomassa florestal
\end{abstract}


quando comparadas com aquelas que se dedicam ao cultivo exclusivo de Milpa e à produção extensiva de gado bovino. O estabelecimento de sistemas silvipastoris, uso dos resíduos agrícolas e o uso de fogões ecológicos podem ser alternativas para reduzir a extração de lenha florestal.

Palavras-Chave: Biomassa acima do solo; Pressão antropogênica; Lenha.

\section{INTRODUCTION}

Nearly 2.7 billion people in the planet depend on traditional fuels like firewood, charcoal and animal dung for domestic energy (IEA, 2011). But the demand and sources of energy vary depending on regions. In many countries, these resources account for over $90 \%$ of household energy consumption (IEA, 2013). In Mexico, total energy consumption from the residential sector in 2015 was of $755.5 \mathrm{PJ}$, of which $33.5 \%$ was obtained from fuelwood (SENER, 2018). About one fourth of Mexican households (27.2 million people) depend, either exclusively (18.7 million people) or in combination with liquefied petroleum gas (LP gas) (8.5 million people), on fuelwood for cooking (Masera et al., 2005). High fuelwood consumption is concentrated especially within rural and peri-urban households in Mexico (Masera et al., 2005). In the state of Chiapas, nearly $50 \%$ of the families depend on firewood as their main source of energy for cooking and heating their homes. The average per capita fuelwood consumption in the rural communities of El Ocote, Chiapas, ranged from 1.3 to $3.3 \mathrm{~kg} \mathrm{day}^{-1}$ (Marquez-Reynoso et al., 2017) to $9.5 \mathrm{~kg}$ day $^{-1}$ person $^{-1}$ in two rural communities of Villaflores, Chiapas (López-Cruz, 2016).

The high demand for this resource contributes significantly to deforestation, forest degradation and loss of biodiversity (Marquez-Reynoso et al., 2017). The total forest biomass removal for fuelwood in Mexico increased from 0.47 to 0.63 million $\mathrm{m}^{3}$ between 1990 and 2011 (FRA, 2015). Since the total forested area in Chiapas has greatly decreased in the past decades due to the expansion of pasturelands, fuelwood pressure on the remaining forest patches has been increasing. Despite the high demand for fuelwood by the families living around or adjacent to frontier forests, there are few studies that evaluate changes in the biomass storage of remnant forests as a consequence of fuelwood extraction (García-Oliva et al., 2014). The purpose of this research was to evaluate the biomass stocks of the pine and oak forests between four rural communities with different fuelwood extraction pressure in Chiapas,
Mexico. The study also addressed possible technical and ecological alternatives for fuel saving and forest conservation in the region where fuelwood is the main source of household energy.

\section{MATERIALS AND METHODS}

To evaluate the changes in forest cover in Chiapas, we compiled published reports presenting total forest area at different times and analyzed the INEGI vegetation and land use maps (III, IV and V series). Four sites within the municipality of Villaflores, Chiapas, were selected to evaluate forest biomass considering the gradient of fuelwood extraction pressure. Niquidambar and Belen are the high fuelwood pressure sites and Nambiyugua and Jerusalen are considered the low fuelwood pressure sites. Easy access to the community and the demand for firewood were the criteria adopted to define fuelwood pressure. Apiculture and agroforestry practices are common livelihood activities in low fuelwood pressure sites, while extensive animal farming and maize monoculture are predominant in high fuelwood pressure sites. Pine forest is the main vegetation type in Niquidambar and Nambiyugua, while the oak forest predominates in Belen and Jerusalen. Villaflores is located in the southern limits of the central depression and the Sierra Madre de Chiapas, of predominantly mountainous terrain. Its geographical coordinates are $16^{\circ} 14.0^{\prime} \mathrm{N}$ and $93^{\circ} 16.0^{\prime} \mathrm{W}$. The predominant climate in the region is tropical sub-humid with annual precipitation ranging from $1200 \mathrm{~mm}$ to $1600 \mathrm{~mm}$. The average monthly temperatures range from $19^{\circ} \mathrm{C}$ to $29^{\circ} \mathrm{C}$. Leptosols and Cambisols are the dominant soil types at the study sites.

To evaluate land use changes over time within the selected sites, we used a participatory historical mapping approach and field visits with geo-referencing. Land use changes were analyzed using the ArcGis software. Forest Biomass stocks of pine and oak forests were quantified by measuring dasometric variables within 16 forest monitoring plots of $400 \mathrm{~m}^{2}$ (four plots by community). Stand structural parameters like tree diameter

Revista Árvore. 2018;42(3):e420307 
at breast height (DBH), total height of the tree, canopy diameter and branch free trunk height were also measured. Published allometric equations (Eq. 1, 2 and 3) were used to calculate aboveground biomass (Cairns et al., 2003; Vargas-Loreta et al., 2017). Equations 1 and 2 (VargasLoreta et al., 2017) use the sum of different biomass components calculated separately. For equation 3 (Cairns et al., 2003), wood density corrections were applied because the original equation did not include the wood density parameter.Eq.1

Pine (Pinus sps.)

$$
\begin{aligned}
& \mathrm{AGB}=\left[\left(0.01753 * \mathrm{DBH}^{1.8261} \mathrm{TH}^{1.28397}\right)+\right. \\
& \left(0.02898 * \mathrm{DBH}^{2.08978}\right)+\left(0.00948 * \mathrm{DBH}^{2.7493}\right)+ \\
& \left.\left(0.04163 * \mathrm{DBH}^{1.93601}\right)\right] / 1000
\end{aligned}
$$

Oak (Quercus sps.)

$$
\begin{aligned}
& \mathrm{AGB}=\left[\left(0.01988 * \mathrm{DBH}^{2.28684} * \mathrm{TH}^{0.52175}\right)+\right. \\
& \left(0.05621 * \mathrm{DBH}^{2.0764}\right)+\left(0.11276 * \mathrm{DBH}^{1.52164} \mathrm{TH}^{0.53343}\right) \\
& \left.+\left(0.0377 * \mathrm{DBH}^{1.42193} \mathrm{TH}^{0.70675}\right)\right] / 1000
\end{aligned}
$$

Other species:

$$
A G B=\frac{\operatorname{Exp}\left(-2.12605+0.868 \operatorname{Ln} D B H^{2} * T H\right) P / P m}{1000}
$$

Where, AGB is aboveground living tree biomass $(\mathrm{Mg}), \mathrm{DBH}$ is the diameter at breast height $(\mathrm{cm}), \mathrm{TH}$ is the total height of the tree $(\mathrm{m}), P$ is the wood density of each tree species $\left(\mathrm{g} \mathrm{cm}^{-3}\right)$, and $P m$ is the mean wood density of the tree species used to develop the equation $\left(0.72 \mathrm{~g} \mathrm{~cm}^{-3}\right)$.

Basal areas were calculated as the sum of the crosssectional areas of the tree trunks at the height of 1.3 $\mathrm{m}$ from ground level. All trees within each plot were measured and extrapolated per hectare.. Linear regression analysis was performed to evaluate the temporal trend of forest cover changes in Chiapas. One-way ANOVA $(p=0.05)$ was used to compare the statistical differences in forest biomass and stand structural properties between the sites with high and low fuelwood pressure.

\section{RESULTS}

\subsection{Changes in forest cover}

In Chiapas, forest areas have decreased sharply over time. Nearly $40 \%$ of the total forest lands have been converted to other land uses during the past 60 years (Figure 1).

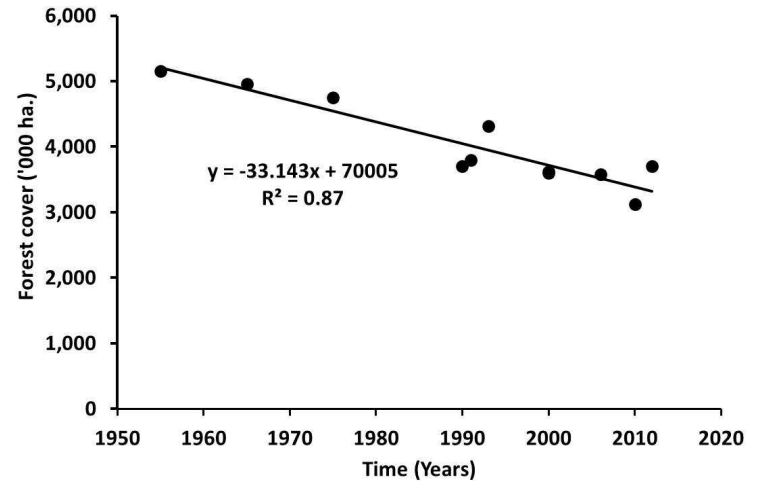

Figure 1 - Forest cover decrease over time in Chiapas, Mexico. Data compiled from different published reports.

Figura 1 - Redução da cobertura florestal ao longo do tempo em Chiapas, México. Dados compilados de diferentes relatórios publicados.

Land use pattern changes between two communities of Chiapas, one with high fuelwood pressure and the other with low fuelwood pressure, varied strongly over time. The loss of forest cover from 1995 to 2015 was of $70 \%$ at the high fuelwood pressure site, compared to $15 \%$ at the low fuelwood pressure site (Figure 2).

\subsection{Changes in forest structure and biomass storage}

Fuelwood pressure greatly affected the stand structural properties of both the pine and oak forests as many of them varied between two sites. Average tree $\mathrm{DBH}$, tree height, basal area and canopy diameter were significantly higher $(\mathrm{p}<0.05)$ at the low fuelwood pressure site, compared to the high fuelwood pressure

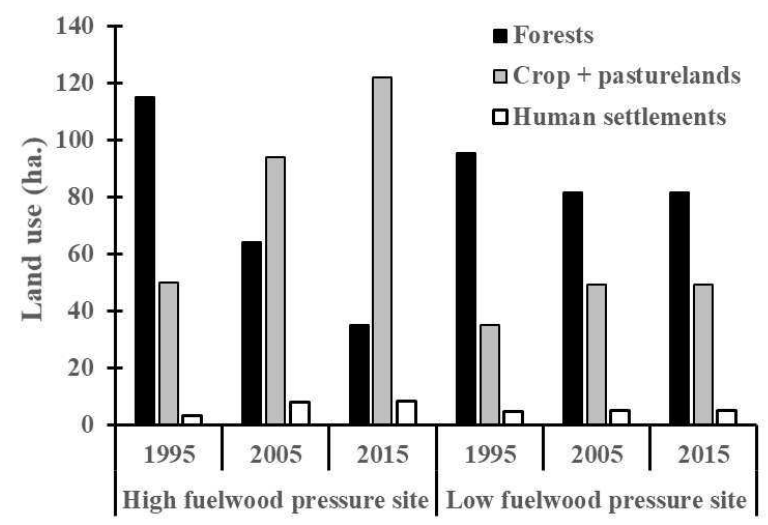

Figure 2 - Differences in land use pattern changes between two communities of Chiapas.

Figura 2-Diferenças entre duas comunidades de Chiapas no seu padrão de mudança no uso da terra.

Revista Árvore. 2018;42(3):e420307 
Table 1 - Structural variation of pine and oak forest between sites with high and low fuelwood pressure in Chiapas, Mexico.

Tabela 1 - Variação estrutural em florestas de pinus e carvalho entre sítios com alta e baixa pressão de lenha em Chiapas, México.

\begin{tabular}{|c|c|c|}
\hline $\begin{array}{l}\text { Stand } \\
\text { structural } \\
\text { characteristics }\end{array}$ & $\begin{array}{l}\text { Low fuelwood } \\
\text { pressure site }\end{array}$ & $\begin{array}{l}\text { High fuelwood } \\
\text { pressure site }\end{array}$ \\
\hline \multicolumn{3}{|l|}{ Pine forests } \\
\hline Tree DBH $(\mathrm{cm})$ & $25.81( \pm 2.89)^{\mathrm{a}}$ & $17.00( \pm 1.45)^{\mathrm{b}}$ \\
\hline Tree height (m) & $16.75( \pm 1.37)^{\mathrm{a}}$ & $13.81( \pm 0.80)^{\mathrm{b}}$ \\
\hline $\begin{array}{l}\text { Basal area } \\
\left(\mathrm{m}^{2} \mathrm{ha}^{-1}\right)\end{array}$ & $26.81( \pm 0.07)^{\mathrm{a}}$ & $21.7( \pm 0.03)^{\mathrm{b}}$ \\
\hline $\begin{array}{l}\text { Tree density } \\
(\text { no. of stems ha-1) }\end{array}$ & 419 & 769 \\
\hline $\begin{array}{l}\text { Canopy diameter } \\
(\mathrm{m})\end{array}$ & $5.72( \pm 0.48)^{\mathrm{a}}$ & $3.84( \pm 0.23)^{\mathrm{b}}$ \\
\hline $\begin{array}{l}\text { Wood specific } \\
\text { gravity }\left(\mathrm{g} \mathrm{cm}^{-3}\right)\end{array}$ & $0.55( \pm 0.01)^{\mathrm{a}}$ & $0.55( \pm 0.01)^{\mathrm{a}}$ \\
\hline $\begin{array}{l}\text { Trunk height to } \\
\text { first branching }(\mathrm{m}) \\
\text { Oak forests }\end{array}$ & $6.07( \pm 0.57)^{\mathrm{a}}$ & $5.52( \pm 0.46)^{\mathrm{a}}$ \\
\hline Tree DBH $(\mathrm{cm})$ & $17.31( \pm 2.22)^{\mathrm{a}}$ & $10.31( \pm 0.87)^{\mathrm{b}}$ \\
\hline Tree height (m) & $7.32( \pm 0.48)^{\mathrm{a}}$ & $5.48( \pm 0.21)^{\mathrm{b}}$ \\
\hline Basal area $\left(\mathrm{m}^{2} \mathrm{ha}^{-1}\right)$ & $40.31( \pm 7.03)^{\mathrm{a}}$ & $26.57( \pm 5.51)^{\mathrm{b}}$ \\
\hline $\begin{array}{l}\text { Tree density } \\
(\text { no. of stems ha-1) }\end{array}$ & 1181 & 3025 \\
\hline $\begin{array}{l}\text { Canopy diameter } \\
(\mathrm{m})\end{array}$ & $8.40( \pm 1.02)^{\mathrm{a}}$ & $3.45( \pm 0.18)^{\mathrm{b}}$ \\
\hline $\begin{array}{l}\text { Wood specific } \\
\text { gravity }\left(\mathrm{g} \mathrm{cm}^{-3}\right)\end{array}$ & $0.71( \pm 0.02)^{\mathrm{a}}$ & $0.71( \pm 0.02)^{\mathrm{a}}$ \\
\hline $\begin{array}{l}\text { Trunk height to } \\
\text { first branching (m) }\end{array}$ & $3.19( \pm 0.24)^{\mathrm{a}}$ & $2.54( \pm 0.17)^{\mathrm{b}}$ \\
\hline
\end{tabular}

site (Table 1). However, tree density per hectare was higher at the high fuelwood pressure site. There were no significant differences in average wood density and branch free trunk height between sites. The lower basal area and higher tree density at the high fuelwood pressure site were explained by the presence of shorter and smaller trees, which is one of the common symptoms of forest degradation. Such differences in forest structural properties are normally linked to the variation in their biomass storage capacity.

The aboveground biomass (AGB) stocks varied significantly between the sites with different level of fuelwood pressure (ANOVA, $F=7.95, p=0.018$ ). Pine and oak forests with low fuelwood pressure stored, respectively, 213.374 and $189.51 \mathrm{Mg}$ of AGB ha $^{-1}$. The AGB stock was $35 \%$ and $51 \%$ lower for pine and oak forests, respectively, at the high fuelwood pressure sites (Figure 3).

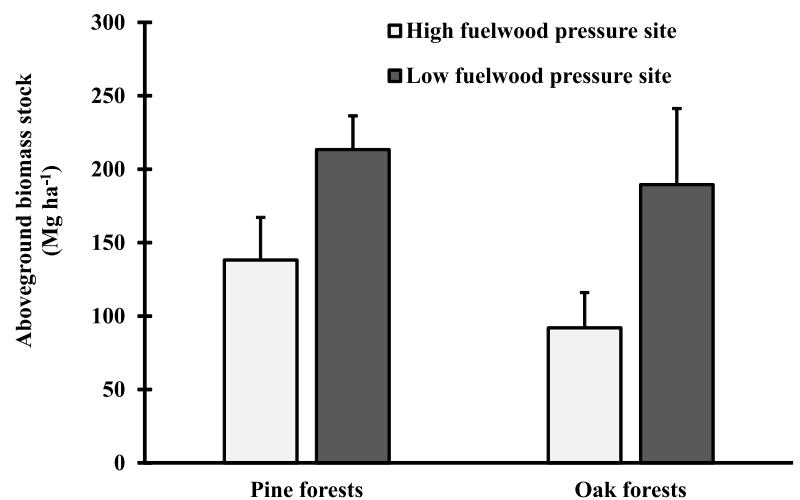

Figure 3 - Aboveground biomass storage in pine and oak forests in two communities with different fuelwood demand in Chiapas, Mexico. Vertical bars represent the confidence interval of 0.95 .

Figura 3 - Estoque de biomassa acima do solo em florestas de pinus e carvalho em duas comunidades com diferentes demandas de lenha em Chiapas, México. Barras verticais representam o intervalo de confiança de 0,95 .

\section{DISCUSSION}

Deforestation for the expansion of pasture and agricultural lands was very high between the 70s and the 90s because of governmental incentives in Mexico. In recent years, it has been reported that the intense deforestation in southern and southeastern Mexico has declined, and that secondary vegetation is growing. However, degradation of the remaining forests due to the extraction of fuelwood and other forest products is still ongoing in rural areas of Mexico because of household energy demand (Rüger et al., 2008; Barody, 2013; De Jong, 2013). Land use changes at community scale can be attributed to the differences of main livelihood activities between the two communities. Apiculture was the main livelihood activity at the low fuelwood pressure site, whereas crop and livestock production were the main livelihood activities at the high fuelwood pressure site.

Easy access from the rural community increased fuelwood extraction, thereby reducing total AGB storage. Livelihood activities like apiculture require conservation of natural flora and this explains the highest level of forest conservation in one of the communities analyzed in this study. Rüger et al. (2008) also reported similar changes in forest structure and tree community composition due to fuelwood harvesting in tropical montane cloud forests of Veracruz, Mexico. González-

Revista Árvore. 2018;42(3):e420307 
Tagle et al. (2011) demonstrated that firewood extraction increased canopy openness and decreased leaf area index values in a pine-oak forest of Nuevo Leon, Mexico. GarcíaOliva et al. (2014) stated that carbon storage in aboveground biomass and soil and litter production decreased with the intensity of forest degradation caused by unmanaged firewood extraction in Cuitzeo basin, Michoacan, Mexico. Ghilardi et al. (2009) reported that about $8 \%$ of the total forest area in the Purepecha region of Michoacan is subjected to nonrenewable fuelwood extraction. Over-extraction of some species due to differed fuelwood preferences can have long term impact on forest species composition (Marquez-Reynoso et al., 2017).

Understanding tree growth, recruitment and mortality at different stages of forest succession can be a useful tool in the adequate harvesting of the correct species without deviating the successional trajectories, species composition and carbon dynamics (Aryal et al., 2014). The average per capita fuelwood consumption in these communities was of $9.5 \mathrm{~kg}_{\text {person }}{ }^{-1}$ day $^{-1}$ (López-Cruz, 2016). Marquez-Reynoso et al. (2017) reported that fuelwood consumption in the communities around the El Ocote biosphere reserve of Chiapas ranged from 1.3 to $3.3 \mathrm{~kg}_{\text {person }}{ }^{-1} \mathrm{day}^{-1}$. Alternative strategies like improved cooking stoves can save up to $26 \%$ of fuelwood consumption and related greenhouse gas emissions (García-Frapoli et al., 2010; Vázquez-Calvo et al., 2016). From ecological perspectives, the establishment of dendroenergy banks, the management of agroforestry systems and secondary forests for family fuelwood consumption would be the sustainable alternatives in rural areas with high fuelwood demand (McCrary et al., 2005; Sharma et al., 2016).

\section{CONCLUSION}

Fuelwood demand in rural areas significantly reduces forest area and biomass stocks of the adjacent forest ecosystems. Ecofriendly livelihood activities like apiculture were more efficient in forest conservation compared to extensive agriculture and livestock production activities. Continued extraction of some species due to their preferred fuelwood properties can change the stand structure and community composition of the forest ecosystems. Technological and ecological alternatives like improved cooking stoves, the establishment of dendroenergy banks, and the management of agroforestry systems are recommended for a sustainable fuelwood supply to people living in rural areas around the frontier forests.

\section{ACKNOWLEDGEMENTS}

The authors are thankful to Consejo Nacional de Ciencia y Tecnología (CONACYT) for financing the project "Estrategias de mitigación de impactos ambientales del sector agropecuario en Chiapas (3812015)" and to Alianza MéxicoREDD+ for supporting field work. Thanks to Noé Alejandro Ruiz Orantes for his support in laboratory works. We appreciate the comments from two anonymous reviewers on the earlier version of the document.

\section{REFERENCES}

Aryal DR, De Jong BH, Ochoa-Gaona S, EsparzaOlguin L, Mendoza-Vega J. Carbon stocks and changes in tropical secondary forests of southern Mexico. Agriculture Ecosystems and Environment. 2014;195(1):220-30.

Baroody JJ. Firewood extraction as a catalyst of pine-oak forest degradation in the highlands of Chiapas, Mexico [dissertation]. Washington:

University of Washington, School of

Environmental and Forest Sciences; 2013.

Cairns MA, Olmsted I, Granados J, Argaez J. Composition and aboveground tree biomass of a dry semi-evergreen forest on Mexico's Yucatan Peninsula. Forest Ecology Management. 2003;186(1):125-32.

De Jong BHJ. Spatial distribution of biomass and links to reported disturbances in tropical lowland forests of southern Mexico. Carbon Management. 2013;4(6):601-15.

FRA. Global forest resource assessment 2015. Rome: Food and Agriculture Organization of the United Nations; 2015.

García-Frapolli E, Schilmann A, Berrueta M, RiojasRodríguez H, Edwards RD, Johnson M, et al. Beyond fuelwood savings: valuing the economic benefits of introducing improved biomass cookstoves in the Purépecha region of Mexico. Ecological Economics. 2010;69(1):2598-605.

García-Oliva F, Covaleda S, Gallardo JF, Prat C, Velázquez-Durán R, Etchevers JD. Firewood extraction affects carbon pools and nutrients in remnant fragments of temperate forests at the Mexican Transvolcanic Belt. Bosque. 2014;35(3):311-24.

Revista Árvore. 2018;42(3):e420307 
Ghilardi A, Guerrero G, Masera O. A GIS-based methodology for highlighting fuelwood supply/ demand imbalances at the local level: a case study for central Mexico. Biomass and Bioenergy. 2009;33(1):957-72.

González-Tagle MA, Jiménez-Pérez J, Himmelsbach W. Impact of firewood extraction on leaf area index and canopy openness in mixed pine-oak forests in northeast Mexico. Forstarchiv. 2011;82(1):20-5.

International Energy Agency - IEA. World Energy Outlook 2013. Chapter 2 Extract: Modern Energy for All. Paris: 2013.

International Energy Agency - IEA. World energy outlook 2011. Paris: 2011.

López-Cruz A. Alternativas tecnológicas para la mitigación de emisiones de $\mathrm{CO}_{2}$ por el uso de leña en dos comunidades del municipio de Villaflores (dissertation). Chiapas: Universidad Autónoma de Chiapas, Facultad de Ciencias Agronómicas; 2016. 83p.

Marquez-Reynoso MI, Ramírez-Marcial N, CortinaVillar S, Ochoa-Gaona S. Purpose, preferences and fuel value index of trees used for firewood in El Ocote Biosphere Reserve, Chiapas, Mexico. Biomass and Bioenergy. 2017;100(1):1-9.

Masera O, Díaz R, Berrueta V. From cookstoves to cooking systems: the integrated program on sustainable household energy use in Mexico. Energy for Sustainable Development. 2005;9(1):25-36.

McCrary JK, Byron W, Hammett AL. Species, sources, seasonality, and sustainability of fuelwood commercialization in Masaya, Nicaragua. Forest Ecology and Management. 2005;205: (1):299-309.

Rüger N, Williams-Linera G, Kissling D, Huth A. Long-term impacts of fuelwood extraction on a tropical montane cloud forest. Ecosystems. 2008;11(1):868-81.

Sistema de Información Energética - SENER. Secretaria de Energía (SENER), México: 2018. [accessed on: 2018 Feb 01]. Available at: http:// sie.energia.gob.mx/ bdiController.do action $=$ cuadro \&cvecua=IE7C03.

Sharma N, Bohra B, Pragya N, Ciannella R, Dobie1 $\mathrm{P}$, Lehmann, S. Bioenergy from agroforestry can lead to improved food security, climate change, soil quality, and rural development. Food and Energy Security. 2016;5(3):165-83.

Vargas-Larreta B, López-Sánchez CA, Corral-Rivas JJ, López-Martínez JO, Aguirre-Calderón C. G, Álvarez-González JG. Allometric equations for estimation of biomass and carbon stocks in temperate forests of north-western Mexico. Forests. 2017;8(1):269-89. 